\title{
Employment in the post-pandemic period: problems and prospects (regional aspect)
}

\author{
Lyubov Krylova, Anna Prudnikova, and Natalya Sergeeva*
}

Financial University under the Government of the Russian Federation, Leningradskiy prospect, 49, 125993 Moscow, Russia

\begin{abstract}
The COVID-19 pandemic has fundamentally changed the employment situation, both globally and within individual states. Several tens of millions of people in the world were left without work. The unemployment rate, both statistically confirmed and hidden, has risen significantly. Only the most developed and richest countries were able to restrain the rapid growth in the number of unemployed through budget transfers. At the same time, the era of social distancing contributed to the revision of work standards in many industries, changed the conditions of employment and the requirements of employers to employees. The forced transition of thousands of institutions to remote work was a catalyst for the digital economy and led to the emergence and rapid growth of new clusters of professions of the future. The world after the pandemic will no longer be the same, and in the field of employment in the first place.
\end{abstract}

\section{Introduction}

COVID-19 has dramatically changed the job market and the workplace. According to statistics, tens of millions of people in the world have lost their jobs due to the coronavirus. However, economists are confident that the official unemployment figures do not reflect the real state of affairs.

Hidden unemployment is also growing significantly in the world. It has always existed, but now the shadow army of citizens who are not employed, but also not accounted for as unemployed, has grown. Because when assessing the labor market on the basis of monthly surveys of the population, statisticians consider people without work only those who are actively looking for it and are ready to start immediately.

The statistical office of the European Union admitted that the indicators of employment and unemployment, determined by the International Labour Organization (ILO), in this particular situation do not fully reflect what is happening.

There is a direct relationship: where the volume of budgetary spending on anti-crisis support is higher, the loss of the labor market is less. This statement is asserted by ILO estimation.At the same time, there are signs of improvement in employment.

The pandemic accelerated the digitalization of all spheres of society and sectors of the economy, identified the need for digital skills and led to the active formation of new clustersof professions of the future.

\footnotetext{
* Corresponding author: sergeeva69@mail.ru
} 


\section{Materials and Methods}

It should be noted that unemployment is the situation of actively looking for employment, but not being currently employed. Eurostat defines an unemployed person as someone aged 15 to 74 (in Italy, Spain, the UK, Iceland, Norway: 16 to 74 years), without work during the reference week, available to start work within the next two weeks (or has already found a job to start within the next three months) and actively having sought employment at some time during the last four weeks [1].

According to EUROSTAT, the unemployment rate increased by a quarter in the EU from March to August of the current year [1]. The situation has temporarily stabilized, but so far there is no hint of an increase in employment, and since the growth rate of COVID19 cases does not decrease, unfortunately, there is no reason for optimism.

And, as STATISTA states [2], this indicator more than tripled in the USA in April 2020 after the outbreak. The situation is gradually improving, however, the epidemiological situation in the country is still tense, so a rapid reduction in the unemployment rate is not worth waiting for.

According to ILO, the number of hours worked globally during the peak of the first wave of COVID-19 fell by the equivalent of 500 million jobs, and earnings fell by $10 \%$ [3]. Experts say that $\$ 12$ trillion was spent on subsidies to the population and business in the world, and most of these funds were provided by the governments of developed countries. As the ILO confirms, if not for these astronomical injections, mass layoffs would have punched a $\$ 3.5$ trillion hole in family budgets. But money is rapidly running out even in developed countries, subsidies are melting, and all this promises a surge in unemployment. First of all, this may affect European states, where out of 190 million employees, one in three received state support to one degree or another[4]. According to economists, real unemployment in France, Italy, Spain and Great Britain is 3-5 percentage points higher than the official one. According to their calculations, every fifth European resident of those whose salaries were shifted onto the shoulders of taxpayers during the lockdown runs the risk of being left without a job when the authorities cut off anti-crisis funding.

Companies on both sides of the Atlantic are confirming these concerns. They vied with each other to promise reductions. And they are doing this only now, six months after the start of the pandemic, since their internal reserves are depleted, a second wave of coronavirus looms on the horizon, and the authorities are gradually curtailing state support. Dozens of the largest companies reported mass layoffs and sending workers on indefinite unpaid leave in October 2010. For example, the Walt Disney Company announced the layoff of 28,000 theme park workers in the US, where no one else goes. European oil and gas concern Royal Dutch Shell will cut 9 thousand rates, and the German company Continental plans to cut or outsource 30 thousand employees worldwide. A catastrophic situation has developed in the air transportation industry. For example, in the United States, more than 150 thousand airline workers have already been fired or sent on leave without pay. At the end of October 2020, United announced its readiness to cut 12 thousand jobs [1]. And that's just big international business.

The growth of hidden unemployment is also quite natural. Pensioners, students, and those who despaired of finding a job and abandoned their search are not considered to be economically active population and are not taken into account. Namely, during the pandemic, the share of the latter increased sharply, because people of many professions soberly assess their prospects, looking at boarded up shop windows and empty airports. And if they are not looking for work, then they are not considered unemployed. This embellishes the official statistics, but not for long. A good example is the USA. In America, unlike in Europe, employees on forced leave are immediately classified as unemployed, and therefore unemployment at the peak of the pandemic increased there not by a fraction of a 
percent, but soared from a historically insignificant $3.5 \%$ to $14.7 \%$, or almost 23 million person. And by the fall, it had halved, partly because the economy revived, and partly because the Americans, who were looking for work in April but found nothing over the summer, had lost hope by September and did not get into the so-called "economically active population", in proportion to which unemployment is calculated. As a result, with the official September account of 12.6 million unemployed, the real number of Americans who have lost their earnings due to the virus exceeds 20 million, as follows from the calculations of specialists from the Economic Policy Institute [5].

Many are still employed, but with reductions, reduced employment and reduced wages. Others, having lost one permanent job with a good salary, are interrupted by various temporary earnings: couriers, taxi drivers, tutors. The number of jobs is growing, but the number of workers is still the same, and their income is even lower. Taking into account those who lost their salaries or switched to part-time work, more than 30 million people became victims of the pandemic in the United States. State statisticians themselves do not hide the fact that their bulletins do not reflect the real state of affairs on the labor market during the pandemic. According to Eurostat economists, in the second quarter of 2020, which saw the first wave of coronavirus infections and lockdowns, the gap between labor supply and demand in the EU was $14 \%$, while official unemployment did not exceed $6.5 \%$ [1].

The longer the period for which people leave the labor market, the harder it is for them to return to it as competitive workers. The longer the break in your career, the lower your chances of finding a job at the same level. As a result, inequality is growing, fraught with social tension and political instability. And not only nationally, but also internationally: between rich countries and those that are poorer.

According to Allianz economist's calculations, the virus has made 13 million Brazilians and almost two million Chileans unemployed, and real unemployment in Brazil is 10 percentage points higher than the official one, and 15 in Chile.And in Spain, according to the country's central bank, unemployment has reached $20 \%$ and risks staying at this level for at least two more years, since this country has suffered more than its neighbors not only from the virus, but also from a lockdown due to the fact its economy is stronger other European countries relies on the restaurant and hotel business.

In the second quarter of 2020, 195 million people were employed in the EU. Professionals, which encompasses people highly skilled in domains such as science and engineering, health, teaching, business and administration, information and communications technology and legal, social and cultural field, is the most common occupational group among EU workers (21\% of total employment). They are followed by 'technicians and associate professionals' $(17 \%)$, 'service and sales workers' $(16 \%)$, 'craft and related trade workers' (12\%) and 'clerical support workers' (10\%).

At the other end of the scale, fewer than one in ten workers had an 'elementary occupation' (e.g. cleaners and helpers, labourers, food preparation assistants, street and related sales and service workers) $(8 \%)$, or were working as 'plant and machine operators and assemblers' (7\%), 'managers' $(5 \%)$ or 'skilled agricultural, forestry and fishery workers' $(4 \%)$ [1].

In the second quarter of 2020, we can see the fall in the number of temporary contracts corresponds to $80.5 \%$ of the total decrease in employment for this age group.

Youth employment has been particularly affected. From the last quarter of 2019 to the second quarter of 2020, the share of temporary contracts in employment changed from $46.2 \%$ to $42.7 \%$ for young people aged $15-24$ while it only decreased from $11.6 \%$ to $10.2 \%$ for the population aged 20-64.

The decline in employment with temporary contracts was visible in all EU Member States, apart from Lithuania and Denmark. The most substantial shrinkages were found in 
Latvia, Bulgaria, Malta, Slovenia, Estonia, Greece and Slovakia, where the decrease exceeded $20 \%$.

The number of people employed part-time also fell over the same period, dropping from 33.8 to 31.0 million, a decrease of 2.8 million among people aged 20-64. Please take note that the group of people with temporary contracts overlaps the group of part-time workers.

Fewer people employed part-time were also recorded in 20 out of 26 EU Member States for which data is available, with drops of more than $10 \%$ in Ireland, Spain, Malta, Portugal and Latvia. However, part-time employment increased by more than $10 \%$ in Hungary $(27.7 \%)$ and Bulgaria (10.9\%).

In the USA, according to the Robert Half special report, workers are adapting and feel supported:77\% of employees have been working from home since the pandemic emerged, $63 \%$ of professionals realize their job is doable from home and $97 \%$ of workers said their manager has been a source of support during this challenging time [5].

Nevertheless, the labor market is showing signs of improvement. Bright spots bring optimism:

1. More than 18 million unemployed professionals who were temporarily laid off due to work slowdowns or business closures expect to return to work.

2. The unemployment rate for college-degreed workers 25 and older, under $7 \%$, is below the national unemployment rate, which is near $11 \%$.

3. Many companies have learned that the remote work is a viable option, and employees enjoy having the flexibility: $79 \%$ said their job allows the windowed work, or the ability to block their day into chunks of business and personal time, and $73 \%$ of those workers said it leads to greater productivity.

4. Workers have become more comfortable using technology for remote work and $60 \%$ said the lack of a commute have improved their work-life balance.

5. Human resources leaders reported that the majority of organizations are using new virtual technology to interview candidates due to the COVID-19 pandemic.

6. Small business owners expect the recession to be short-lived, and nearly $40 \%$ anticipate better business conditions in the next 6 months.

Employers must pay attention to employees' post-pandemic expectations:

- $74 \%$ of professionals would like to work remotely more often than before the outbreak. More parents (79\%) expressed this preference;

- $\quad 55 \%$ would like staggered work schedules;

- $\quad 79 \%$ think their companies should have better cleaning procedures;

- $52 \%$ feel their employers should require workers to wear masks;

- $46 \%$ want their employers to change the office layout in an effort to maintain social distancing.

The situation is no better in Russia. Underemployment has increased dramaticallyin the country. At large and medium-sized enterprises in the first quarter of 2020, part-time employment was $3.8 \%$, in the second quarter - already $6.3 \%$. The most difficult situation has developed in Yakutia, the Samara region, and the Perm Territory [6].

A new trend for Russia is the rapid growth of registered unemployment, as in developed countries. We have had it for the first time since the 1990s. There was a five-fold increase in registered unemployment at the end of August: at the end of February,2020 it was less than $1 \%$, but now it is already $4.8 \%$.

The reasons are an increase in the level of benefits to a living wage and a sharply simplified registration, less paperwork and can be done online. It is estimated that about $40 \%$ of the registered unemployed had no previous legal job.

Registered unemployment grew the fastest in Moscow, St. Petersburg, and the Moscow region - 7-8 times. But there the pre-crisis level was minimal, only $0.4 \%-0.6 \%$, and in August 2020 it already ranged from 3 to $3.5 \%$. This is a consequence of the crisis primarily 
in the service sector. The level of registered unemployment (7-8\%) is twice as high in industrial regions with a large decline in industrial production. However, the leaders, as usual, are the republics of the North Caucasus and Tuva.

The number of regions in which the unemployment rate was $10 \%$ or higher, increased over the year from six to 13. This is evidenced by the data of RIA Novosti research [7].

The unemployment rate in Russia at the end of June-August 2020 amounted to $6.3 \%$. This is 1.9 points higher than a year earlier. According to the research, the highest unemployment rate $(30.7 \%)$ is observed in Ingushetia Republic. Tyva Republic (22.3\%) and Chechen Republic (21.7\%) follow.

The regions where unemployment is $10 \%$ or more include Tomsk region (10\%), Omsk region $(10.2 \%)$, Kalmykia Republic $(10.2 \%)$, Khakassia Republic (10.3\%), Buryatia Republic (10.6\%), AltaiRepublic (13.6\%), Karachay-Cherkess Republic (14.9\%), Kabardino-Balkar Republic (15.4\%), Dagestan Republic (16.1\%) and Republic of North Ossetia - Alania (16.3\%). The lowest unemployment rate was recorded in the YamaloNenets Autonomous Okrug (2.5\%), in Moscow (2.7\%) and in the Khanty-Mansi Autonomous Okrug (3.2\%).

This summer, job search took an average of 5.9 months. By August, $18.5 \%$ of the unemployed had been looking for work for 12 months or more, according to the survey data. In September, unemployment continued to rise. At the end of the month, the number of officially registered unemployed increased 5.5 times compared to September last year and reached 3.7 million people.

The RIA Novosti research is based on data from Rosstat. It compared the number of unemployed by the standards of the International Labor Organization with the size of the labor force, and also determined the average time to find a job.

According to the Ministry of Labour, by the end of 2021 there will be 71.9 million employed people in Russia [8]. This figure exceeds the figure for July 2020, when Rosstat determined the number of employed at 70.2 million people. Among the tools to increase the level of employment, the Ministry of Labour highlighted measures for the professional retraining of the unemployed, the development of distance employment, the strengthening of interaction between employment centers of different regions and the flow of labor, the development of internship programs for graduates of vocational educational institutions.

\section{Results and Discussion}

Even before COVID-19, workers and workplaces around the world were facing the potential for unprecedented levels of disruption. The tech revolution and the need for a green revolution have created an urgent need to increase access to the skills, tools and financial services workers need for the jobs of tomorrow. Technology has also exacerbated gender gaps, with the largest in roles that rely heavily on disruptive tech skills, with the share of women represented across cloud, engineering and data jobs below $30 \%$.

The pandemic has accelerated the transition to a digital economy - and for those who are able to work from home, the need for digital skills. For those who cannot work from home - such as workers in healthcare, emergency services or the food supply chain - there have been difficult decisions about whether to put yourself and your family at risk as you continue working, if you even have a job to go back to. And COVID-19 has had a disproportionate impact on workers in the informal economy, whose incomes have dropped as much as $81 \%$ in the first month of the pandemic in some regions, as well as on women, who account for $70 \%$ of health and social workers globally.

Disruption to workplaces was happening well before COVID-19 - but the pandemic increased the need for large-scale, informed and collaborative action to prepare for the future of work. 
The World Economic Forum's Future of Jobs Report 2020 finds 84\% of employers “are set to rapidly digitize working processes which includes a significant expansion of remote work - with the potential to move $44 \%$ of their workforce to operate remotely" [9].

For industries where working from home isnot an option, investments are needed to protect workers and jobs. Most urgently, this includes providing workers with PPE, as a recent Forum survey of manufacturing companies found, and possibly rethinking workspaces entirely. Then, employers need turn to challenges like reskilling, professional development and technical adoption.

The Ministry of Labor of the Russian Federation notes that the Russian labor market is gradually recovering, and the number of offers from employers is growing. Already, more than 1.47 million vacancies are presented on the «Work in Russia» portal [10]. At the same time, as noted by job search agencies, employers are still looking for workers for project, part-time or part-time employment, often experimenting with remote work.

According to experts, millions of citizens may leave office in the coming years and start working for themselves. This makes it easy to do the self-employment mode. Since the launch of the «My Tax» application, which quickly and easily allows you to apply for a self-employment regime, more than a million people have signed up. According to the director of the National Guild of Freelancers of Russia, the potential of the freelance market is 10 million people. At the same time, experts name both 5 and 15 million people, and the number of self-employed may rise to these figures.

This difference in assessments is explained by the "shadow" nature of self-employment. According to experts, every tenth working citizen has an additional source of income that is not declared in any way. Many people have part-time jobs, but for various reasons they do not come out of the shadows. Someone simply does not know about the self-employment regime and the simplicity of its registration. Someone is not ready to officially advertise that they have a "hack".

Since the launch of the «My Tax» application, the self-employed have earned 143 billion rubles and paid more than 3.5 billion rubles to the budget. These numbers will gradually increase due to the whitewashing of the additional income market. The most common activities in the "My Tax» application are taxi, delivery of goods, apartment rentals, tutoring, and renovation work. Marketing and IT services are also popular. The number of designers, programmers, analysts, copywriters and other intellectual and creative professions does not exceed $10-15 \%$ of the self-employed, and their number is expected to grow.

According to the Future of Jobs Report 2020, today we can see the emergence of clusters of professions of the future, such as data and artificial intelligence, engineering and cloud computing, and so on.

Employers in the COVID-19 era are faced with a host of new challenges: keeping their businesses running amid economic uncertainty, managing remote workers and maintaining staff morale. There are some ways to boost employee morale: to show workers they are valued, to focus on employee wellness and to pay the top performers well.

In an age of social distancing and teleworking, hiring isnot getting easier. There are some tips for finding new talent in the COVID-19 environment.

Businesses will be flooded with applicants who have been laid off during the pandemic. Sorting through hundreds or potentially thousands of resumes to find needle in the haystack can be overwhelming. The employers should be specific about their must-have requirements in the job description to discourage underqualified applicants.

There are not extra hours to invest in the hiring process even in a good economy. Today the employers have less time, because they have fewer people on staff and more challenges in keeping the business running. And it is necessary to block the calendar during less busy times of the week to limit interruptions and focus on hiring tasks. 
The fact that many jobs can be done remotely now means that the employers can extend their candidate search beyond geographic boundaries. A salary range must takes into account the requirements of the job and the market the candidate lives in.

While there are many more job seekers out of work than there were several months ago, employed professionals remain a key segment of the candidate supply. Working with a recruiter widens the net to include these passive job seekers.

The best candidates may already be on the payroll, that is why the employers should consider opportunities to advance these workers and hire new employees with fresh perspectives to backfill their vacancies.

\section{Conclusions}

1. Remote work is now the new norm as many people remain sheltered in place, and remote hiring and onboarding may also be here to stay.

2. Employees have specific expectations about the post-pandemic workplace.

3. Hiring isnot getting any easier, despite a larger pool of available talent.

4. The COVID-19 pandemic has had a major impact on skills and distance learning.

5 . The economic consequences of the pandemic will see inequality accelerate.

6 . The jobs of the future will be a combination of technical and human skills.

Taking into accountall types of unemployment and its real scale, an extremely dangerous economic chain is built:

- reduction in the number of employed leads to a drop in the income of the population;

- $\quad$ people spend less, and the engine of the economy - consumption - starts to junk;

- government revenues are also falling because taxes on employees are being cut;

- government spending, on the contrary, is growing, since the unemployed need social support: benefits and housing;

- the growth of wages stops and is replaced by a decline due to the surplus of labor;

- there is a very real threat of deflation.

As a result, the prospect of normalizing monetary policy, raising interest rates and increasing interest in savings as a source of investment, through which the economy develops and grows, becomes very illusory and certainly distant.

\section{References}

1. Eurostat, https://ec.europa.eu/

2. STATISTA, https://www.statista.com/

3. International Labour Organization, https://www.ilo.org/

4. A. Di Paolo, A. Ferrer-i-Carbonell, Regional borders, local unemployment and happiness, 202014 (2020)

5. Robert Half, https://www.roberthalf.com/

6. N.V. Gaponenko, J.C. GlennScience and technology, 31, 271(2020)

7. RIA Novosti, https://ria.ru/

8. Ministry of Labour and Social Protection of the Russian Federation, https://mintrud.gov.ru/

9. World Economic Forum, https://www.weforum.org/

10. Portal "Work in Russia", https://trudvsem.ru/ 